\title{
RURAL TOURISM - EMPOWERING LOCAL PEOPLE AND FOSTERING COMMUNITY DEVELOPMENT
}

\author{
Dr. Srijib Shankar Jha \\ Associate Professor, Department of Travel \& Tourism Management, Siliguri Institute of Technology, \\ Sukna, District: Darjeeling (W.B), Pin code: 734009
}

Article DOI: https://doi.org/10.36713/epra7954

DOI No: 10.36713/epra7954

\begin{abstract}
With its rich cultural heritage, historical monuments, and natural resources, India is a world-renowned tourist destination. India's tourism industry has emerged as a major economic driver, generating significant foreign exchange earnings. Tourism is a major global industry, contributing $11 \%$ of global GDP. Rural tourism in India has enormous potential due to India's vast rural diversity. Rural tourism in India is envisioned to create jobs and a vibrant local economy by reviving old art and crafts and preserving rural India culture. A 'counter-urbanization' syndrome has developed as a result of the stress of city living. This has sparked a surge of interest in rural areas. Other causes, such as increased wellness awareness, greater interest in heritage and culture, enhanced accessibility, and environmental sensitivity, are all contributing to the trend toward rural tourism. Following COVID-19, tourist recovery usually begins at a local level. Before there is a strong demand for foreign travel, tourists opt to stay closer to home for a weekend escape or travel locally. Road trips may become more popular. Drive-ins are more likely to be chosen by families and children, especially on weekends and during short vacations. This paper attempts explore the process of 'Rural Tourism' from the point of view of empowering local people and fostering community development.

KEYWORDS : Rural Tourism, community development, sustainability, empowerment.
\end{abstract}

\section{INTRODUCTION}

Rural tourism aims to achieve local sustainable development and provide a sufficient response to modern society's leisure needs within a new social harmony between city and rural. The traditional rural economy, which is based on agriculture, forestry, crafts, and other sectors, benefits greatly from rural tourism. Rural tourism, without a doubt, produces new jobs and helps to support existing businesses as well as start new ones. As a result, rural tourism plays a critical role in rural development, as evidenced by the diversification of economic activities and revenue in rural areas. Aside from that, it encourages the preservation and protection of rural cultural heritage, greater chances for women and disabled people, environmental and biodiversity protection, and so on. the goal of becoming a tourist hub for a variety of niches and generating higher returns, the business should employ systems to attract the right guests and effectively manage the expanding rural tourism locations.
Rural tourism can be defined as human activity in a rural location focused on land-based economics, especially agriculture and farming. Agriculture's economic benefit is mostly dependent on natural factors. Crops would perish owing to natural calamities, such as strong rainfall or a lack of rain, and the lush and lovely area would begin to appear desperate. As a result, rural communities are facing financial difficulties. Traditions, heritage, arts, lifestyles, folklore, customs, natural landscapes, historical landmarks, and more distinguish a distinct rural community. The community benefits from increased employment opportunities, expanded economic growth, social improvement, and the resurrection of local crafts into commerce as a result of tourist boosting in rural areas.

The goal of rural development is to improve the living conditions of those who live in these places. Tourism plays an important part in the expansion of the rural economy and the development of rural standards there. Because it offers a wide variety of villages that 
are both geographically and touristically appealing, it can help to increase economic activity and build infrastructure services. With the growing popularity of niche tourism, the concept of positioning is no longer restricted to brands, but now includes places. The placement of a destination thus entails categorising the location in terms of the type of experience it provides to visitors - each destination is unique and distinct. This not only makes it easier for tourists to identify the proper kind of site for them, but it also allows places to brand themselves in a way that attracts all of the right guests. The transformation of a degraded rural region into a viable rural tourism destination benefits the host community in terms of economic, cultural, social, and environmental development.

The tourism industry is intended to play a significant role in the country's economic development, culture, and human resource development, among other things. At the same time, it has a direct impact on local culture, socioeconomic patterns of life, customs, dietary habits, language, values, and ethics, as well as providing tourists with an enriched tourism experience at tourism locations. The term "rural tourism" refers to any activity that takes place in the countryside. Rural tourism is currently the global trend, and it is also being recognised as an important tool for rural community development. It is described as any type of tourism that exhibits rural life, art, culture, and heritage in rural places, thereby contributing to the economic and social development of the local community and allowing tourists and locals to interact for a more meaningful tourism experience. According to research, psychological factors such as serenity, freedom, and rural traditions, which are in contrast to metropolitan modern life, drive people to visit rural places. Following COVID-19, tourist recovery usually begins at a local level. Before there is a strong demand for foreign travel, tourists opt to stay closer to home for a weekend escape or travel locally. Road trips may become more popular. Drive-ins are more likely to be chosen by families and children, especially on weekends and during short vacations. As a result, tourists are inclined to prefer countryside tourism. Cleanliness and hygiene may be more important to these vacationers than frills and luxury.

The concept of rural tourism in India has been debated extensively in the literature (Pearce 1989; Bramwell 1994; Seaton et al. 1994). Rural tourism is a broad term that encompasses a variety of activities that take place in rural areas. Fourth, global markets, communications, and telecommunications have changed market conditions and orientations for traditional products. To put it simply, it is a 'state of mind' that is measurable and quantifiable (Sharpley \& Sharpley, 1997).

Researchers are constantly adding to their knowledge of rural tourism. There is a strong desire to learn about and experience the history of rural customs, folklore, local traditions, beliefs, and common heritage (Bramwell and Lane in Jolliffe \& MacDonald, 2003). (Pedford in Jolliffe \& MacDonald, 2003). Rural tourism is defined by: 'it is rural in scale, relies on the traditional qualities of the countryside, develops slowly under local control, and is non-uniform (reflecting the complexity of the rural environment)' (Thomson Learning).

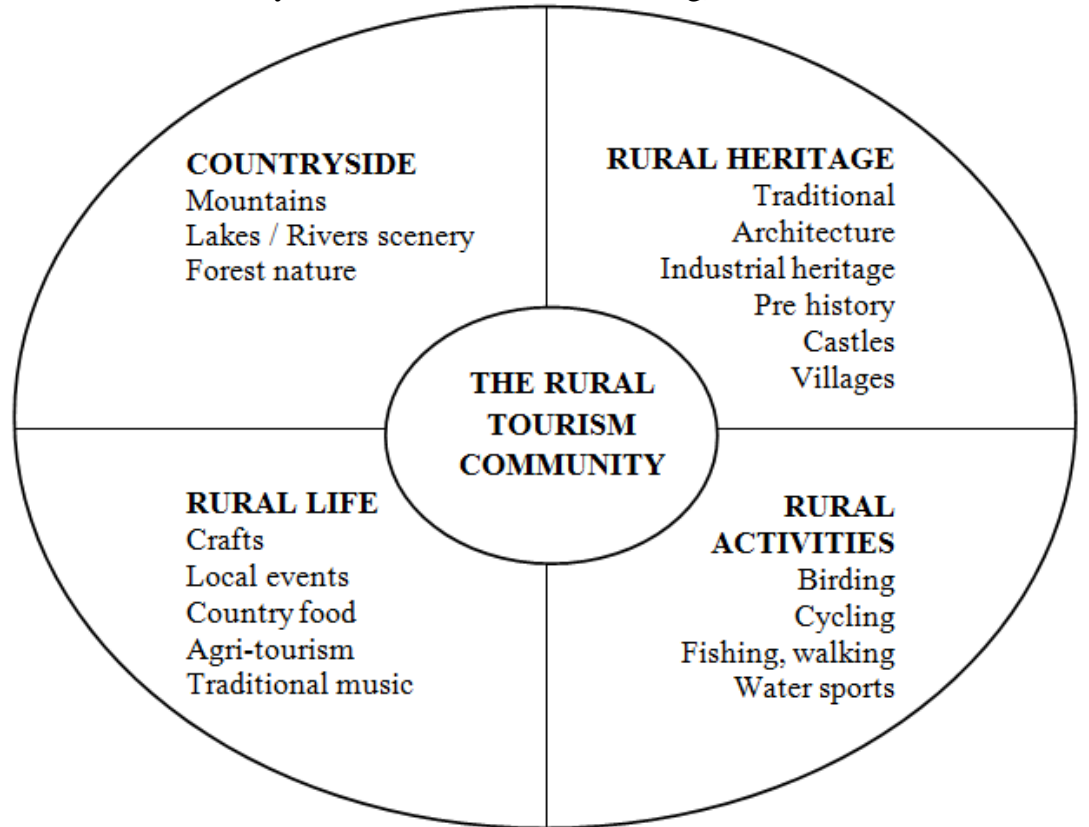

Figure 1. The Rural Tourism Concept (Source:Nulty-2004)

(C) 2021 EPRA ARER | www.eprajournals.com | Journal DOI URL: https://doi.org/10.36713/epra0813 
Rural tourism is defined as having a strong rural culture component. Rural tourism is any tourism that promotes rural life, art, culture, and heritage, thereby benefiting the local community economically and socially. The desire to give visitors personalised contact, a taste of the unique village life, and the opportunity to participate in local activities, traditions, and lifestyles is a distinctive feature of rural tourism products. Traditional values such as local cooperation, trust and reciprocity are harmoniously embedded in rural tourist destinations, creating a unique tourist product that is predominantly small scaled, nature friendly.

Rural tourism is a type of activity that occurs in the countryside. It includes farm/agricultural, cultural, nature, adventure, and ecotourism. Unlike conventional tourism, rural tourism has certain distinct features: It is based on the preservation of culture, heritage, and traditions, and it is based on the preservation of culture, heritage, and traditions. Rural Tourism in India has a lot of potential, though it is still in its infancy. But it grows. There is a huge market. Rurality is rapidly fading, especially in developed nations. Even young urban Indians would want to connect with rural. The experience is novel for both Indians and foreigners.

Rural tourism is a new concept in India, but it is not new in Europe or other parts of the world where parents want their children to learn about rural life. Australia, Canada, and the USA, for example, have rural tourist attractions. Rural tourism includes heritage, farm, pilgrim, adventure, nature, folkways, and ancient culture tourism. India's potential rural tourism destinations include Gujarat, Kerala's backwaters, Punjabi cuisine, Uttar Pradesh's hills, West Bengal's Shanti Niketan, Orissa's dances and songs, Karnataka's Nithyagram tribes, Meghalaya's natural beauty, Andhra Pradesh's folk dances, Sikkim's mask dances, and Nandagaon Banara's Holi.
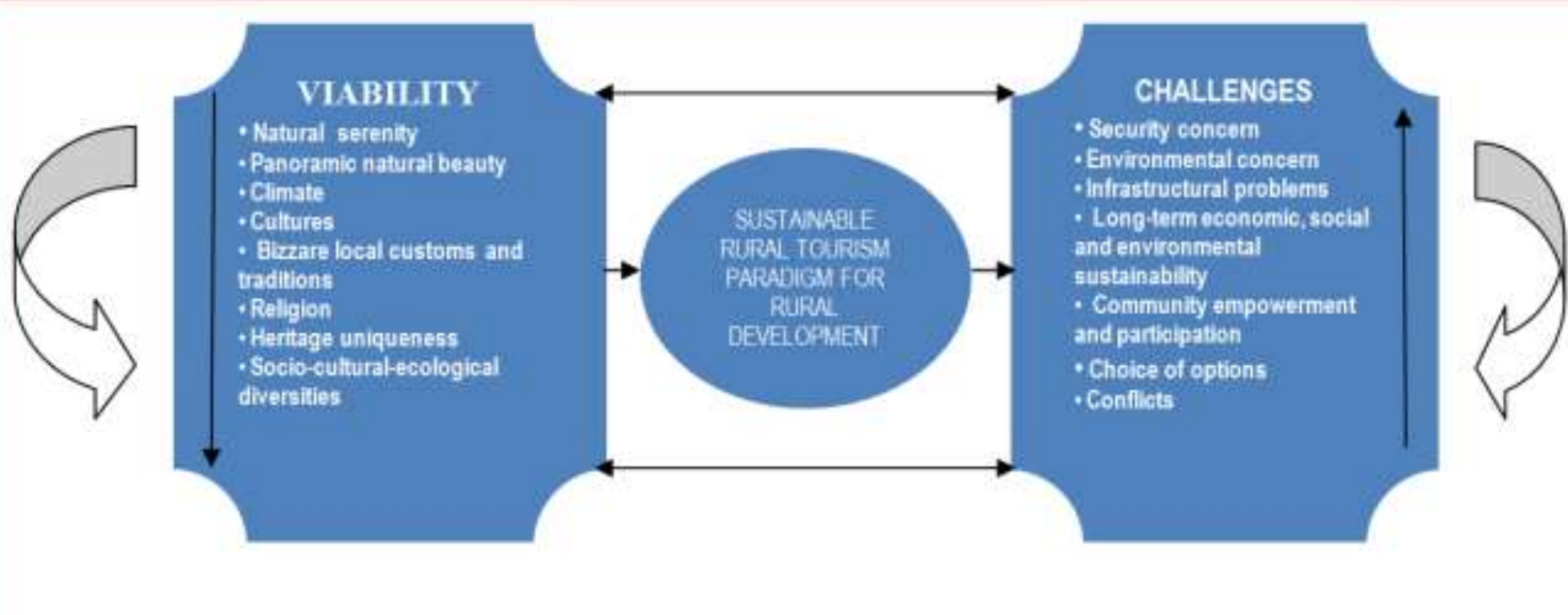

Figure 2. Sustainability continuum (Source:UNWTO)

It is wise to plan tourism industry to promote rural growth and regional development. Other forms of economic activity are promoted by government departments and various public sector agencies in India as agriculture's economic importance to the rural economy declines. Large-scale economic development in rural areas often causes conflict because the majority opposes industrialization, commerce, and building on undeveloped land.

In India, rural tourism is still new, but it will grow. There is a huge market. Many countries' experiences show that rural tourism can be a viable source of income and employment. Tourism can be used as a strategy for rural development. It is important to build a strong platform around Rural Tourism in India, where nearly $74 \%$ of the population lives in villages.

\section{LITERATURE REVIEWS}

According to Urry (1995), one of the most important consequences of reflexivity is increased environmental concern and awareness of the links between local and global environments. Concern for "sustainable" development rises as we move from a "industrial to a "risk" society (Eagles 1992). Local communities play an important role in protecting their natural environment and in global environmental alliances (Richards \& Hall, 2000). The concept of sustainability has gained popularity among place-based communities. This acknowledges that sustainable preservation of the "natural" environment must be grounded in the communities and societies that rely on it (Richards \& Hall, 2000). 
It is based on the observation that current generations place too much demand on the natural environment to allow it to reproduce and maintain itself at its previous level of stability (Butler et al, 1998, p557). The concept of sustainable tourism has been adopted. Human and natural resource systems must be managed in such a way that they can be sustained over time (Reid, 1991). Sustainable tourism is developed and managed using sustainable development principles (Hunter and Green, 1995). The theory of carrying capacity underpins these principles (Butler et al, 1998). Carrying capacity is an ecology term that has been applied to humans, specifically tourists. It is defined as "the maximum number of people who can use a site without causing unacceptable physical or psychological harm to visitors" (Mathieson and Wall, 1982, p168). The quality of the environment and the quality of the recreation experience are the only two components of tourism carrying capacity (Richards and Hall, 2000). Pritchard (1992) adds to Mathieson and Wall's definition of carrying capacity by stating that carrying capacity is concerned with the physical setting's social and psychological capacity to support tourist activity and development. McIntyre and Hetherington (1991) also include the local community, economy, and culture's ability to support tourism

Conservation is a long-standing environmental policy. A policy like this may aim to manage renewable resources like soil, forests, and fisheries in a sustainable manner. With the loss or threat of more of these resources, the importance of conservation grows (Tribe et al., 2000). In rural areas, rural tourism is a type of sustainable tourism that benefits rural areas in terms of rural productivity, employment, wealth distribution, preservation of rural culture, and local people's involvement. Rural tourism can benefit both rural and urban communities. To develop rural tourism, we must first understand the rural environment, demography, socioculture, economics, and politics. How can rural people help their socio-economic situation? To develop a strategic marketing plan for rural tourism, we must first understand our target customers' needs and desires.

Rural tourism will bring people from different cultures, faiths, languages, and lifestyles together and broaden their perspectives. It can create jobs, develop social, cultural, and educational values, and prevent rural-urban migration. Rural tourism can attract tourists by showing them the village atmosphere with local cuisine. Villagers should design and build tourist accommodations in traditional style. Such projects should be able to access attractive bank financing terms. Rural tourism is now a vital component of the tourism industry. There is nothing stopping tourism from reaching the unexplored countryside once the infrastructure is in place. Most influential on social and cultural impacts is Bouqeut and Winter (1987) anthology of studies on rural tourism conflict and political debates. They examine the postwar relationship between tourism, politics, and rural tourism and recreation policies. However, Neate (1987) considers farm-based tourism in the Scilly Isles as a way to diversify the economic base of family farms in a time of declining agricultural profitability.

According to Vincent (1987), rural tourism development necessitates close-knit communities adapting to capitalism's expansion, threatening family independence, traditional values, and cultural traditions. Tourism is one of the few opportunities taken up by women, but it also contributes to their marginal status in the rural workforce. Native people are increasingly involved in tourism to help achieve independence and cultural survival, but tourism development poses unique risks to them. There are also issues with project funding, culturally sensitive training, work and service attitudes, and collective decision-making (Smith, 1997). Tourism will be highly anticipated in communities with low economic activity and tourism development (Johnson et al., 1994). Longterm rural residents are also more likely to support growth and change than newcomers, usually because newcomers moved there for amenities they do not want changed (Getz, 1994).

Many social scientists have studied the economic impact of rural tourism, often emphasising or challenging tourism as a panacea for all rural economic and social ills (Getz, 1981). Butler and Clark acknowledge that rural tourism does not always solve rural development issues due to: "income leakages, volatility, declining multiplier, low pay, imported labour, and investor conservatism." When the rural economy is already weak, promoting tourism will exacerbate income and employment inequalities. It is a better economic supplement than a mainstay of rural

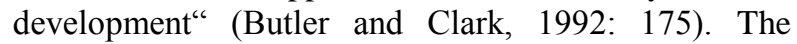
development-intensive nature of tourism and the expansion of mass tourism has posed many new pressures in rural areas as "new tourism" discovers the qualities of rural environments. In fact, rural theme parks, second homes (Gartner, 1987), timeshare, conference centres, and holiday villages have all contributed to the insatiable rural tourism appetite. Several journals recently published special issues on sustainability and rural tourism. However, it is clear that rural tourism exhibits many of the characteristics of the symbolic relationship between tourism and the environment. For these reasons, it is appropriate to consider the tourism resource base, focusing on supply and demand aspects of rural tourism (Page and Getz, 1997). 


\section{METHODOLOGY}

This study's research is divided into numerous sections. To verify the information gleaned from secondary data, primary data was gathered. Interviews and observation were used to gather primary data. Members of the business owners, villagers, working employees, and tourists are among the responders. Secondary data was gathered from books, journals, and other sources.

\section{DISCUSSION}

Rural tourism in India has a bright future, as it preserves not only natural beauty but also local traditions, customs, and foods. Direct interaction with locals can be a unique selling point for tourists. Each state has its own handicrafts, traditions, and foods. Marketing rural tourism products is not an easy task and requires specialisation. Rural tourism could benefit our society greatly if properly promoted. It could be a profitable project for our government's rural development. It can help urban-rural resource flow. It can stop rural-urban migration. Planning, implementation, and monitoring are critical in preventing rural damage. Rural tourism requires environmental management, local participation, sound legislation, sustainable marketing, and realistic planning. Rural tourism should not be mass-marketed. To succeed in rural tourism, different strategies are needed for each segment. It's easy to appeal to everyone. Marketers need to focus on specific segments like newly married couples, families, retirees, youth, foreigners, artists, corporations, etc. to be effective and successful.

Tourism, being a consumer activity, should be demand driven, focusing on visitors' needs and motivations. Thus, the reasons for visiting the villages are seen as a reflection of a growing interest in the outdoors and other general tourist trends. The image of rurality is associated with the tourism and recreation appeal of rural areas. There is a traditional and romantic idea of the "good old days" pure and simple lifestyle, intact nature and perfect human integration in his natural environment. It is necessary to create an environment that allows tourists to experience rurality rather than rushing to create urban comforts in a rural setting. This experience will definitely attract tourists to rural tourism. The natural, cultural, human, or capital resources of the rural area must be appealing to tourists. The attraction (including authenticity), service and facilities quality, accessibility, and pricing are critical factors in determining competitive advantage (perceived as value for money). Finally, with the USP and competitive advantage, the community will need to learn and compete within the market. It is the marketing of a 'experience' that sells rural tourism.
Rural tourism was not given priority by the Indian government until 2002. In 2002, a National Tourism Policy was introduced, focusing on rural tourism to create jobs and promote sustainable livelihoods. 'The Ministry of Tourism is developing and promoting rural tourism sites with core competency in art, craft, culture, heritage, handloom, etc.' The Indian government recognised the challenges and opportunities for rural tourism. The Ministry of Tourism funded rural tourism promotion. The government encouraged each state to involve rural residents in tourism projects developed by tourism officials in consultation with local residents and NGOs. These projects were designed to give tourists a taste of local cuisine, art, and culture. It was decided that the key elements for developing rural tourism were building infrastructure, restructuring and liberalising policies, promoting investment and maintaining law and order. In India, the Ministry of Tourism and the UNDP have joined forces to promote rural tourism. These 36 pilot project sites across the country provided a wealth of knowledge about the intersection of community dynamics and tourism projects. The Endogenous Tourism Project-Rural Tourism Scheme (ETP-RTS) is a 2003 collaboration between the Ministry of Tourism, Government of India, and the United Nations Development Programme (UNDP). While the project's primary goal is to promote sustainable livelihoods, it has a much broader scope than simply creating jobs and increasing income. Sustainability, gender equality, empowerment of women, youth and other disadvantaged groups are all aims of the project. To be a transformative agent capable of changing minds, values and behaviour of tourists and locals alike - as well as providing a broad impetus to local economies across India, tourism needed to be 'radically altered in design and concept'.

Inspired by the success of its 'Incredible India' campaign, the tourism ministry is now promoting rural tourism. The 'explore rural India' campaign has identified over 167 rural tourism projects. The tourism ministry is also focusing on teaching villagers tourismrelated skills. It has partnered with the UNDP to provide vocational training to locals. The ministry allocated five million for rural infrastructure development, while UNDP provided two million per site for skill development. The project involves both hardware and software development. The aim of the project is to improve capacity building, tourism promotion, and market linkage support for the host communities. 


\section{SUCCESS STORIES OF RURAL TOURISM IN INDIA}

Hodka village won the PATA Gold Award 2010 for its rural tourism project in India. The community of Hodka, a village near Bhuj (63 kms), owns and operates Shaam-e-Sarhad (Sunset at the Border) Rural Resort. Hodka village is surrounded by stunning natural beauty, making it an ideal base to explore Kachchh. Kachchh is famous for its arts and crafts and for migratory birds in winter. The Shaam-e-Sarhad Rural Resort, managed by the rural village community, is the perfect gateway to a unique travel experience in India. The resort can sleep 30 people. Tenting costs $\$ 40$ per night and bhungas are around $\$ 60$ per night. Visits to nearby archaeological sites of the Indus Valley Civilization and pashumela, a cattle fair, are popular attractions. The village community organises, packages, and sells all of these activities. Shaam-eSarhad Rural Resort is an excellent example of how local communities can come together and execute an eco-tourism concept that increases awareness of local arts and crafts and employment.

Another example is the Anegundi Rural Tourism Project in Karnataka, which is close to the world famous Hampi. The village on the banks of the mighty river Tungabhadra, with ancient temples, vernacular houses, true village traditions, cultures and festivals. Due to its proximity to the World Heritage Site, the village was sleepy a decade ago. The village was forbidden from doing any construction, especially rebuilding old houses. With the help of the local people, the village community has begun a process of social and economic empowerment through conservation of natural and architectural heritage. Villagers developed rural tourism through riverside landscaping, local tradition revival, and cultural activities. They created software, tourism awareness programmes, local heritage and vernacular architecture, culture, traditions, and art, and made tourism a livelihood strategy.

The successful agro-tourism experience of Malegaon village in Baramati taluk of Pune is a classic example of agro-tourism in Maharashtra. The agrotourism venture benefits the community. Attractions include farm tours; tractor and bullock cart rides; grapes and mango farms; horticulture farms and by-product farms; bird and animal farms; jaggery making unit; Emu bird farm; sugar factory; Taluka Milk Collection Centers; village temple and museum. The overnight stay is at the farm. The agro-tourism venture changed the farmers' lives by increasing their annual income by $25 \%$. They became entrepreneurs after learning soft skills like customer service and marketing. Many Indian villages have succeeded in developing rural tourism concepts, marketing them, and gaining social and economic benefits from their efforts.

\section{SUGGESTIONS - MANAGEMENT OF RURAL TOURISM IN INDIA}

Rural tourism can help some of our rural villages develop sustainably. Governments should prioritise rural tourism and help create a competitive business environment. The local community NGO should work with the government to develop rural tourism destinations and thus provide high quality service to tourists. Creating adequate facilities and suitable infrastructure like accommodation, roads, airport facilities, rail facilities, local transport, communication links and other essential amenities are some of the suggestions to promote rural tourism.

- Restructuring and liberalisation of rural tourism policies.

- Encouragement of financial investments in rural and indigenous development

- Identifying villages with high potential for developing rural tourism destinations to showcase rural India's core competencies.

- Lesser-known regions should be promoted to relieve pressure on popular zones.

- Encouraging and involving the local community at all levels.

- Proper documentation of India's rural and tribal heritage for promotional campaigns.

- Continuing to build the Rural Tourism Unit's capacity.

- Improving service quality by being creative and innovative.

- Maintain a rural tourism database and publish an annual report.

- Bridge the gap between the haves and have-nots.

\section{CONCLUSION}

Tourism experiences in rural areas are now an essential part of the modern tourism experience. In addition to promoting social integration and international understanding, rural tourism will undoubtedly emerge as a significant instrument for sustainable human development, including poverty alleviation, job creation, environmental regeneration, and development of remote areas, as well as the advancement of women and other disadvantaged groups in the country. The government should encourage community participation and mobilisation in rural tourism projects in order to ensure sustainable economic development and positive social change. Many rural tourism projects should be supported by the government to ensure sustainable economic development, positive social change, empowering local people and fostering community development.

(C) 2021 EPRA ARER | www.eprajournals.com | Journal DOI URL: https://doi.org/10.36713/epra0813 
Psychological aspects such as calm, freedom, and rural traditions, which contrast with metropolitan modern life, encourage people to visit rural areas, according to studies. Tourist recovery usually starts at a local level after COVID-19. Tourists choose to stay closer to home for a weekend getaway or visit locally before there is a big demand for foreign travel. It's possible that road trips may grow more popular. Families and children are more likely to choose driveins, especially on weekends and during brief vacations. As a result, visitors are more likely to prefer rural tourism. Rural areas are now included in modern tourism. Indeed, rural tourism can aid in the reduction of poverty, the creation of jobs, the regeneration of the environment, and the advancement of women and other marginalised groups, in addition to the promotion of social integration and international understanding through tourism.

\section{REFERENCES}

1. Beeton S., (1999), "Rural tourism policy", Flagstaff, Arizona

2. $\quad$ Butler R., Hall M., Jenkins J., (1998) "Tourism and recreation in rural areas", Wiley, Chichester

3. Cater E., Lowman G., (1994), "Ecotourism: A sustainable option?" Wiley, Sussex

4. Douglas N, Derrett R., (2001), "Special Interest Tourism", Wiley, London

5. Dowling R., Moore S.A., Newsome D., (2001) "Natural area tourism, ecology impacts and management”, Channel View, New York

6. Eagles P., (1992), "The planning and management of environmentally sensitive areas", Longman, London

7. Gartner W.C., (1987) "Environmental impacts of recreational home developments", Annals of tourism research, Volume 10. No.2

8. Going Rural: Tourism Focuses on India's Hinterland Published: December 03, 2009 in India Knowledge@Wharton

9. Gopal. R., Varma. S. and Gopinat. R. Rural Tourism Development: Constraints and Possibilities with a special reference to Agri Tourism, IIMK Part XII-Tourism Other Sectors.

10. Haldar Pilai . Rural Tourism - Challenges and Opportunities. International Marketing Conference on Marketing \& Society, 8-10 April, 2007, IIMK

11. Hall D., Brown F., (2000) "Tourism in peripheral areas", Channel View, Clevedon

12. Holden A., (2000), "Environment and tourism", Routledge, London

13. Lane B., (1994), "What is rural tourism", Journal of sustainable tourism Volume 2, No.7

14. Mathieson A., Wall G., (1992), "Tourism: economic, physical and social impacts", Longman, London

15. Mieczkowski Z., (1995), "Environmental issues of tourism and recreation" University press of America, Maryland
16. Neate $S$. , (1987), "The role of tourism in sustaining farm structures”, Aldershot, Avenbury

17. O'Halloran M., (2000), "Rural tourism in Australia", school of tourism and hospitality, La Trobe University

18. Page J., Getz D., (1997), "The business of Rural tourism”, Thomson Business Express, London

19. Prichard $W$., (1992), "Changing the essence, the art of creating and leading fundamental change in organizations", Jossey-Bass, San Francisco

20. Rajiv Kumar, Service Quality in Rural Tourism: A Prescriptive Approach, Conference on Tourism in India - Challenges Ahead, 15-17 May 2008, IIMK Adarsh Journal of Management Research (ISSN 0974-7028) - Vol. : 9 Issue : 1 March 201669

21. Rathod, Nisha. Rural Tourism Impact, Challenges and Opportunities. ZENITH International Journal of Business Economics \& Management Research, Vol.2, Issue 2.

22. Redefining Tourism - Experiences and Insights from Rural Tourism Projects in India. Ministry of Tourism, Government of India / UNDP India 2008.Rural Torism pdf file.

23. Reid D., (1991), "Sustainable development, an introductory guide", Earthscan, London

24. Richards G., Hall D., (2000), "Tourism and sustainable community development", Routledge, New York

25. Smith V., Eadington W., (1992), "Tourism alternatives, potentials and problems in the development of tourism", Wiley, Chichester

26. Smith V., Wilde P., (1977), "The multiplier impact of tourism in Tasmania”, Sorret, Melburne

27. Tribe J., Font X., Griffiths N., Vickery R., Yale K., (2000) "Environmental management for rural tourism and recreation", Cassell, London

28. Vincent J.A., (1980), "The political economy of alpine development", Sociologia ruralis 20 (3-4)

29. Wearing S., Neil J., (1999), “Ecotourism: impacts, potentials and possibilities”, ButterworthHeinemann, London

30. Winter M., (1987), "Conflict and practise in rural tourism”, Ecos: a review for conservation 5(3): 1015

31. The Wall Street Journal, January 15, 2010, ET, Going Rural: Tourism Focuses on India's Hinterland, accessed on December 2, 2011. 